\title{
The Effect Of Antioxidants On The Side Effects Of Pegylated Interferon/Ribavirin Combination Therapy In Patients With Chronic Hepatitis C
}

\author{
Ahmed Farouq, Amr A Mourad, Ahmad M Mahmoud, \\ Maged B Abd El-Aziz, Soha A Elhawari, Ahmad S Behiry \\ Tropical Medicine Department, Faculty of Medicine, Zagazig University, Egypt
}

Corresponding Author Ahmed Farouq Omar

Mobile:

+2(0106) 7441166-

$+2(055) 2605547$

E mail:

farouqmail2000@yaho $\underline{\text { o.com }}$

Received :5/9 /2012

Accepted after

revision: $22 / 12$

$/ 2012$

Key words:

Chronic hepatitis $\mathrm{C}$, antioxidants, peginterferon, ribavirin
Background and study aim: Combined anti-hepatitis $\mathrm{C}$ therapy with pegylated interferon and ribavirin is associated with numerous side effects that affect both patients' compliance and response rates. These side effects are believed to be, in part, due to oxidative stress induced by ribavirin. In the present work, we tried to evaluate if antioxidants can ameliorate the side effects of this therapy in patients with chronic hepatitis $\mathrm{C}$ (CHC).

Patients and methods: Two hundred selected patients with $\mathrm{CHC}$ were randomized to receive either the standard antiviral combination therapy (Peginterferon and Ribavirin) plus antioxidant mixture (slow release vitamin C $500 \mathrm{mg}$ daily, vitamin E $400 \mathrm{mg}$ daily, silymarin $420 \mathrm{mg}$ daily and $\mathrm{N}$ acetylcystein $600 \mathrm{mg}$ daily) for 48 weeks (study group, group I) or to receive the standard combination therapy only for 48 weeks (control group, group II). Patients were followed up during the whole treatment course to assess the occurrence of subjective and laboratory side effects of the combined antiviral therapy.
Results: The results of our study revealed statistically significant difference between both groups regarding changes in hemoglobin concentration along therapy from week one onwards as reduction in hemoglobin concentration along therapy was significantly lower in group $\mathrm{I} ; \mathrm{p}=$ 0.001. The frequency of significant anemia $(\mathrm{Hb}<10 \mathrm{gm} / \mathrm{dl})$ in group I was significantly lower than Group II from week twelve onwards; $p$ value ranged from 0.013 to 0.001 . Moreover, the frequency of fatigue was significantly lower in group I from week two onwards till the end of therapy; $p$ value ranged from 0.027 to $<0.001$. On the other hand, all other checked side effects either subjective or laboratory revealed a non significant statistical difference between both groups.

Conclusion: The use of an antioxidant mixture with antiviral combination therapy in patients with $\mathrm{CHC}$ can improve treatment associated anemia and fatigue but has no effect on other treatment associated side effects.

\section{INTRODUCTION}

Hepatitis $\mathrm{C}$ virus (HCV) is one of the main causative agents of chronic viral hepatitis which can progress to cirrhosis and eventually to hepatocellular carcinoma over a period of 20 to 30 years [1]. According to WHO, Egypt has a very high prevalence of $\mathrm{HCV}$ which is higher than neighboring countries as well as other countries in the world with comparable socioeconomic conditions and hygienic standards. Approximately $20 \%$ of Egyptian blood donors are anti-HCV positive [2].
The mechanisms by which $\mathrm{HCV}$ causes cell damage are not well understood. Different mechanisms have been suggested including immunological liver damage, direct cytotoxicity and oxidative stress induction. The theory of "oxidative stress induction" is supported by several lines of evidence including the presence of increased levels of lipid peroxidation products and diminished levels of reduced glutathione in peripheral blood. [3]. 
Combined antiviral therapy with pegylated interferon and ribavirin has been recommended as a standard therapy for patients with CHC. These drugs are given for either 48 weeks (HCV genotypes 1, 4, 5, and 6) or for 24 weeks (HCV genotypes 2 and 3) [4]. Unfortunately, this combination therapy is associated with numerous side effects that affect both patients' compliance and response rates [5]. Such effects are, in part, due to oxidtive stress induced by ribavirin. Ribavirin exerts its antiviral activity after intracellular phosphorylation to its monophosphate, diphosphate and triphosphate which are the pharmacologically active forms; resulting in relative deficiency of adenosine triphosphate (ATP) within red blood cells [6]. This deficiency of ATP may affect the antioxidant defence mechanisms indirectly and hence increase susceptibility to oxidative damage and extravascular hemolysis [7].

An antioxidant is a molecule capable of slowing or preventing the oxidation of other molecules. Oxidation is a chemical reaction that transfers electrons from a substance to an oxidizing agent. Oxidation reactions can produce free radicals, which can start chain reactions and lead to cell damage or death. Antioxidants terminate these chain reactions by removing free radical intermediates, and inhibit other oxidation reactions by being themselves oxidized [8]. Although increased ROS levels in patients with CHC may be beneficial by suppressing $\mathrm{HCV}$ replication [9], many studies have demonstrated the beneficial effects of antioxidants on these patients [10].

\section{Aim of the work}

The present study aims at evaluating the role of certain antioxidant mixture (slow release vitamin C $500 \mathrm{mg}$ daily, vitamin E $400 \mathrm{mg}$ daily, silymarin $420 \mathrm{mg}$ daily and $\mathrm{N}$-acetylcystein 600 $\mathrm{mg}$ daily) in amelioration of the side effects of pegylated interferon/ribavirin combination therapy in patients with $\mathrm{CHC}$.

\section{PATIENTS AND METHODS}

This is a randomized controlled study carried out at the Department of Tropical Medicine, Zagazig University Hospitals from August 2009 to July 2012. This study comprised 200 patients with CHC under pegylated interferon/ribavirin combination therapy. They were all candidates to begin combination therapy according to guidelines of the National Committee for
Control and Prevention of viral Hepatitis " $\mathrm{C}$ " in Egypt. Patients were selected by stratified random sample and assigned into two equal groups; Group I (study group) included 100 patients received combined antiviral therapy (Peginterferon and Ribavirin) plus antioxidants (slow release vitamin C $500 \mathrm{mg}$ daily, vitamin E $400 \mathrm{mg}$ daily, silymarin $420 \mathrm{mg}$ daily and $\mathrm{N}$ acetylcystein $600 \mathrm{mg}$ daily) for 48 weeks and Group II (control group) included 100 patients received combined antiviral therapy (Peginterferon and Ribavirin) only for 48 weeks.

All the studied patients were subjected to the following:

- Complete history taking.

- Complete physical examination.

- Body mass index (BMI).

- Investigations: including complete blood count, liver function tests, kidney function tests, prothrombin time \& INR, fasting blood sugar (and $\mathrm{Hb} \mathrm{A1c}$ if diabetic), pregnancy test in females, anti-HCV, HBs Ag, ANA, TSH (Before treatment and every 12 weeks), alfa feto protein, fundus examination, ECG, pelvi abdominal ultrasound, quantitative HCV RNA assessment (before treatment, after 12 weeks, after 24 weeks and at the end of the course) and liver biopsy for histological staging and grading of chronic $\mathrm{HCV}$.

Treatment regimens: The dose of peginterferon alpha-2a is 180 ug subcutaneously around the umbilicus once per week together with ribavirin using $1000 \mathrm{mg} /$ day for those $\leq 75 \mathrm{~kg}$ in weight and $1200 \mathrm{mg} /$ day for those $>75 \mathrm{~kg}$ in weight. The dose of peginterferon alph- $2 \mathrm{~b}$ is $1.5 \mathrm{ug} / \mathrm{kg}$ body weight subcutaneously around the umbilicus once per week together with ribavirin at dose of 800 $\mathrm{mg} /$ day for those weighting $<65 \mathrm{~kg}, 1000 \mathrm{mg}$ for those $>65 \mathrm{~kg}$ to $85 \mathrm{~kg}, 1200 \mathrm{mg}$ for those $>85 \mathrm{~kg}$ to $105 \mathrm{~kg}$ and $1400 \mathrm{mg}$ for those $>105 \mathrm{~kg}$.

Patient Monitoring: All patients were assessed at weeks $0,1,2$ and 4 of treatment and thereafter monthly. At each review, laboratory tests were performed including serum ALT and AST, bilirubin, full blood count and serum creatinine. Body weight and symptom checklist were recorded at each visit and dose modifications to the peginterferon or ribavirin were made when appropriate. 
Statistical Analysis: Data were checked, entered and analyzed using (SPSS version 15). Data were expressed as arithmetic mean $(\mathbf{X}) \pm$ standard deviation (SD) for quantitative variable, number and percentage for qualitative one. Chi-square $\left(\mathbf{X}^{2}\right)$ and $t$ test were used when appropriate. $\mathrm{P}$ value less than 0.05 was considered significant.

\section{RESULTS}

There was a non-significant statistical difference between patients who received combined antiviral therapy (Peginterferon and Ribavirin) plus antioxidants (group I) and patients who received combined antiviral therapy only (group II) regarding age and sex (table 1).

The frequency of fatigue was significantly lower in group I from week 2 onwards till the end of therapy; $\mathrm{p}$ value ranged from 0.027 to $<0.001$ (table 2, figure 1).

Significant statistical difference was noticed between the two groups regarding changes in hemoglobin concentration along therapy from week 1 onwards (table 3, figure 2) as reduction in hemoglobin concentration along therapy was significantly lower in the group $\mathrm{I} ; \mathrm{p}=0.001$ (table 4). The frequency of significant anemia $(\mathrm{Hb}<10 \mathrm{gm} / \mathrm{dl})$ in group I was significantly lower than Group II from week 12 onwards; $p$ value ranged from 0.013 to 0.001 (table 5).

Percentage of discontinuation of the treatment, due to either absence of EVR or hematological complications, was comparable between the two studied groups. There was a non-significant statistical difference between both groups (table $6)$.

Table (1): Age and sex distribution among the studied groups.

\begin{tabular}{|c|c|c|c|c|c|c|}
\hline & \multicolumn{2}{|c|}{$\begin{array}{c}\text { Group I } \\
\text { (Study group) } \\
(\mathbf{N}=\mathbf{1 0 0})\end{array}$} & \multicolumn{2}{|c|}{$\begin{array}{c}\text { Group II } \\
\text { (Control group) } \\
(\mathrm{N}=100)\end{array}$} & $\mathbf{t}$ & $\mathbf{P}$ \\
\hline $\begin{array}{c}\text { Age (years) } \\
X \pm S D \\
\text { Range }\end{array}$ & \multicolumn{2}{|c|}{$\begin{array}{c}37.8 \pm 9.4 \\
19-55\end{array}$} & \multicolumn{2}{|c|}{$\begin{array}{c}39.5 \pm 9.6 \\
19-58\end{array}$} & 1.56 & 0.12 \\
\hline \multirow{2}{*}{$\begin{array}{c}\text { Gender } \\
\text { Male } \\
\text { Female }\end{array}$} & $\mathbf{N}^{\mathbf{0}}$ & $\%$ & $\mathbf{N}^{\mathbf{0}}$ & $\%$ & $\mathbf{X}^{2}$ & $\mathbf{P}$ \\
\hline & $\begin{array}{l}52 \\
48\end{array}$ & $\begin{array}{l}52 \\
48\end{array}$ & $\begin{array}{l}52 \\
48\end{array}$ & $\begin{array}{l}52 \\
48\end{array}$ & 0.0 & 1.0 \\
\hline
\end{tabular}

Table (2): The percentage of Fatigue in both groups during treatment.

\begin{tabular}{|c|c|c|c|c|c|c|c|c|c|c|c|c|c|c|}
\hline & $\begin{array}{c}\text { Week } \\
\mathbf{1}\end{array}$ & $\begin{array}{c}\text { Week } \\
\mathbf{2}\end{array}$ & $\mathbf{4}$ & $\mathbf{8}$ & $\mathbf{1 2}$ & $\mathbf{1 6}$ & $\mathbf{2 0}$ & $\mathbf{2 4}$ & $\mathbf{2 8}$ & $\begin{array}{c}\text { Week } \\
\mathbf{3 2}\end{array}$ & $\begin{array}{c}\text { Week } \\
\mathbf{3 6}\end{array}$ & $\begin{array}{c}\text { Week } \\
\mathbf{4 0}\end{array}$ & $\begin{array}{c}\text { Week } \\
\mathbf{4 4}\end{array}$ & $\begin{array}{c}\text { Week } \\
\mathbf{4 8}\end{array}$ \\
\hline $\begin{array}{c}\text { Group I } \\
(\boldsymbol{\%})\end{array}$ & 64 & 57 & 42 & 34 & 24 & 20 & 14 & 13 & 12 & 4 & 8 & 2 & 4 & 2 \\
\hline $\begin{array}{c}\text { Group II } \\
(\boldsymbol{\%})\end{array}$ & 72 & 72 & 62 & 58 & 46 & 46 & 38 & 37 & 38 & 26 & 30 & 26 & 22 & 20 \\
\hline $\mathbf{X}^{\mathbf{2}}$ & 1.47 & 4.91 & 8.0 & 11.6 & 10.6 & 15.29 & 15.0 & 15.36 & 18.03 & 18.98 & 15.7 & 23.92 & 14.32 & 16.52 \\
\hline $\mathbf{P}$ & 0.23 & 0.027 & 0.005 & 0.001 & 0.001 & $<0.001$ & $<0.001$ & $<0.001$ & $<0.001$ & $<0.001$ & $<0.001$ & $<0.001$ & $<0.001$ & $<0.001$ \\
\hline
\end{tabular}

Group I (Study group), Group II (Control group) 
Figure (1): Shows the difference between both groups regarding the percentage of fatigue.

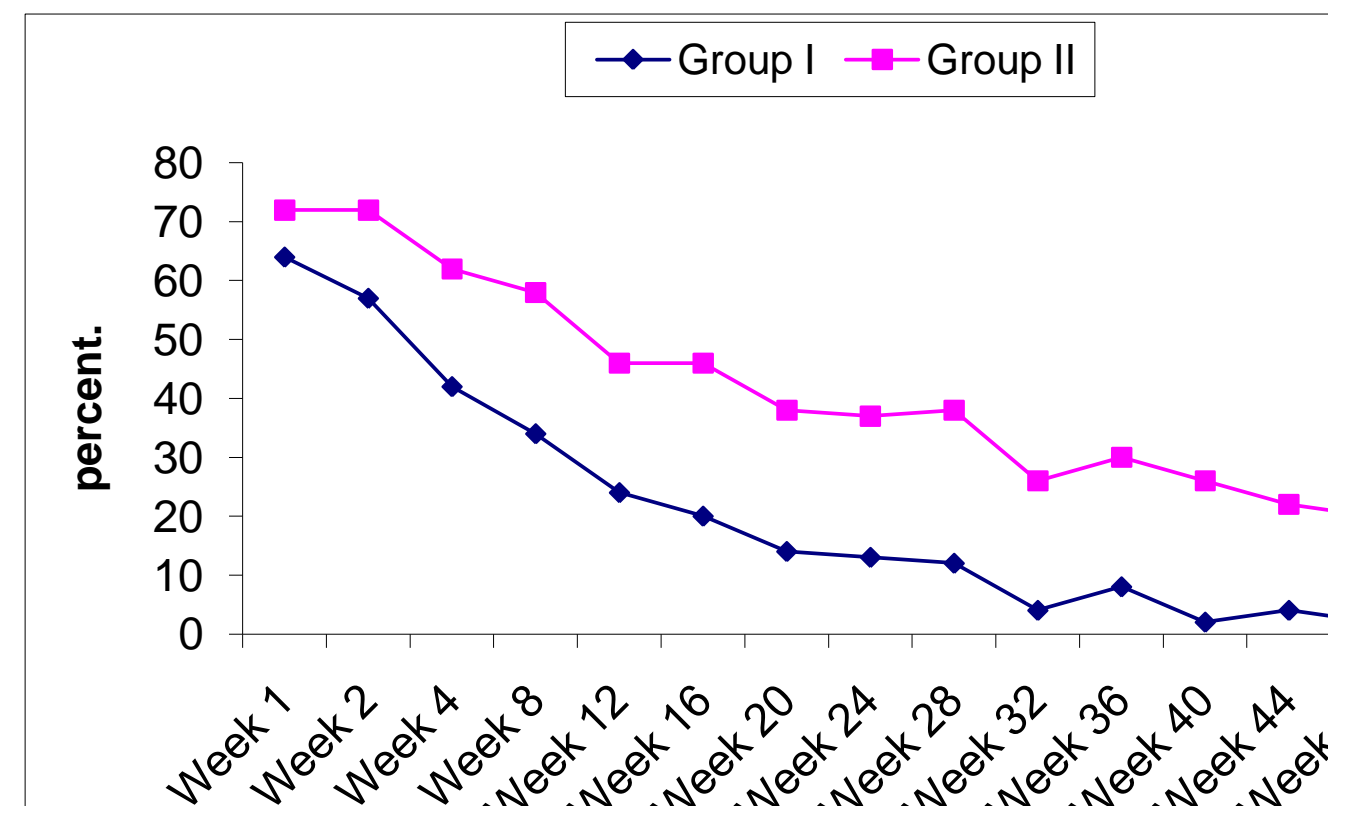

Table (3): Changes in hemoglobin concentration in both groups during treatment.

\begin{tabular}{|c|c|c|c|c|}
\hline & $\begin{array}{c}\text { Group I } \\
\text { (Study group) } \\
(\mathbf{N}=\mathbf{1 0 0})\end{array}$ & $\begin{array}{c}\text { Group II } \\
\text { (Control group) } \\
(\mathbf{N = 1 0 0})\end{array}$ & $\mathbf{t}$ & P \\
\hline Week 0 & $13.8 \pm 1.0$ & $13.75 \pm 1.0$ & 0.14 & 0.88 \\
\hline Week 1 & $13.77 \pm 0.97$ & $13.2 \pm 1.0$ & 3.5 & 0.001 \\
\hline Week 2 & $13.2 \pm 0.97$ & $12.6 \pm 1.03$ & 4.1 & 0.001 \\
\hline Week 4 & $12.5 \pm 1.1$ & $11.99 \pm 1.17$ & 3.29 & 0.001 \\
\hline Week 8 & $11.9 \pm 0.9$ & $11.5 \pm 1.1$ & 2.9 & 0.004 \\
\hline Week 12 & $12.0 \pm 1.1$ & $11.3 \pm 1.1$ & 4.65 & 0.001 \\
\hline Week 16 & $12.0 \pm 1.1$ & $11.2 \pm 1.1$ & 5.13 & 0.001 \\
\hline Week 20 & $11.9 \pm 1.2$ & $11.0 \pm 1.2$ & 4.88 & 0.001 \\
\hline Week 24 & $11.85 \pm 1.2$ & $10.9 \pm 1.3$ & 5.26 & 0.001 \\
\hline Week 28 & $11.63 \pm 1.4$ & $10.9 \pm 1.3$ & 3.5 & 0.001 \\
\hline Week 32 & $11.6 \pm 1.3$ & $10.9 \pm 1.3$ & 3.5 & 0.001 \\
\hline Week 36 & $11.6 \pm 1.4$ & $10.9 \pm 1.4$ & 3.6 & 0.001 \\
\hline Week 40 & $11.63 \pm 1.4$ & $10.89 \pm 1.3$ & 3.5 & 0.001 \\
\hline Week 44 & $11.6 \pm 1.39$ & $10.9 \pm 1.4$ & 3.5 & 0.001 \\
\hline Week 48 & $11.5 \pm 1.3$ & $10.67 \pm 1.2$ & 4.5 & 0.001 \\
\hline
\end{tabular}


Figure (2): Shows changes in hemoglobin concentration in both groups during treatment.

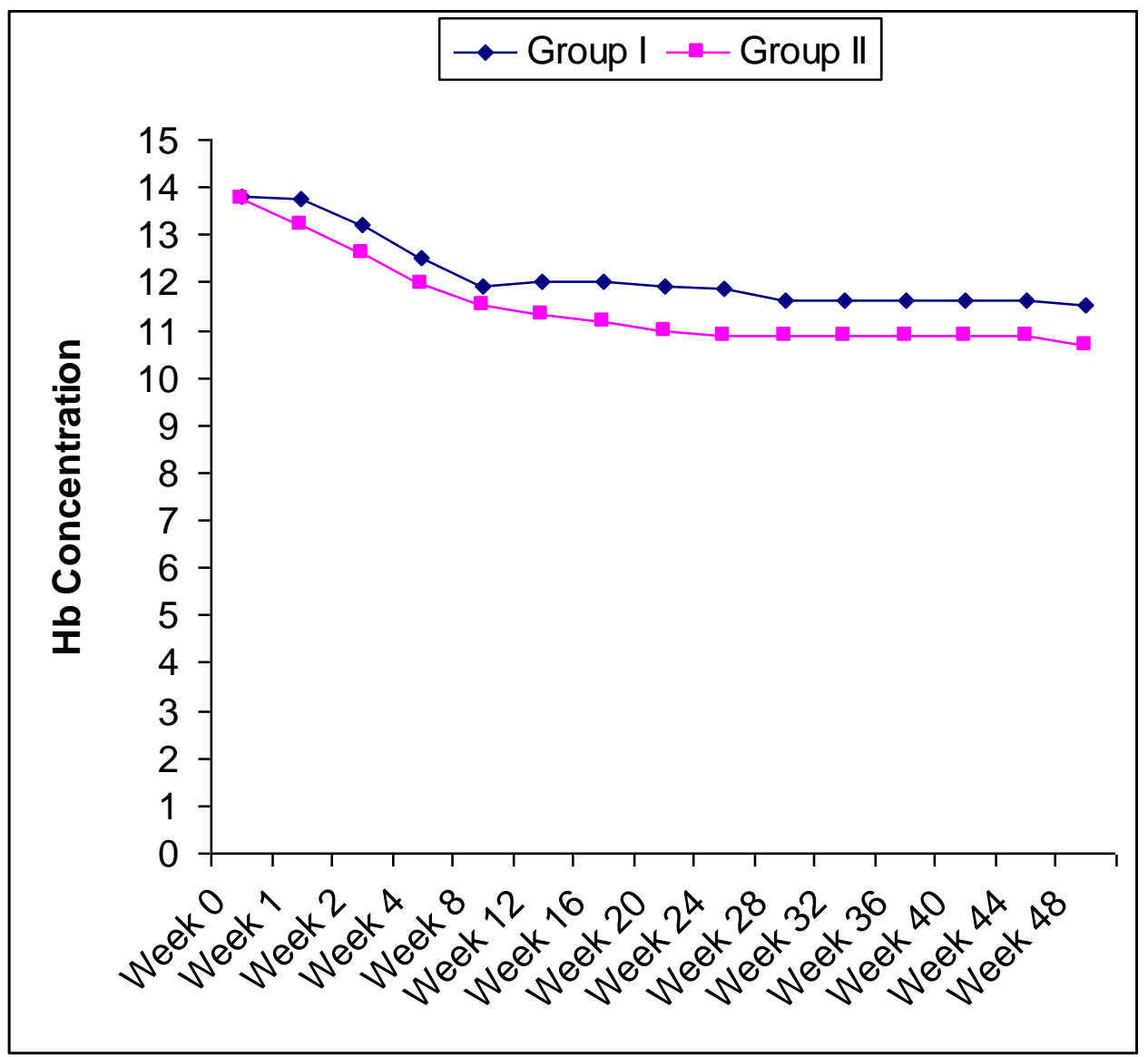

Table (4): Mean reduction in hemoglobin concentration in both groups along therapy.

\begin{tabular}{|c|c|c|c|c|}
\hline & $\begin{array}{c}\text { Group I } \\
(\text { Study group }) \\
(\mathbf{N}=\mathbf{1 0 0})\end{array}$ & $\begin{array}{c}\text { Group II } \\
\left(\begin{array}{c}\text { Control group) } \\
(\mathbf{N}=100)\end{array}\right.\end{array}$ & $\mathbf{t}$ & $\mathbf{P}$ \\
\hline $\mathbf{X} \pm \mathbf{S D}$ & $2.4 \pm 1.5$ & $3.2 \pm 1.6$ & 3.7 & 0.001 \\
$\mathbf{\%}$ & 16.5 & 22.3 & 2.7 \\
\hline
\end{tabular}

Table (5): The percentage of significant anemia $(\mathrm{Hb}<10 \mathrm{gm} / \mathrm{dl})$ in both groups.

\begin{tabular}{|c|c|c|c|c|c|c|c|c|c|c|c|c|c|c|}
\hline & $\begin{array}{c}\text { Week } \\
\mathbf{1}\end{array}$ & $\begin{array}{c}\text { Week } \\
\mathbf{2}\end{array}$ & $\mathbf{4}$ & $\mathbf{8}$ & $\mathbf{1 2}$ & $\mathbf{1 6}$ & $\mathbf{2 0}$ & $\mathbf{2 4}$ & $\mathbf{2 8}$ & $\mathbf{3 2}$ & $\mathbf{3 6}$ & $\begin{array}{c}\text { Week } \\
\mathbf{4 0}\end{array}$ & $\begin{array}{c}\text { Week } \\
\mathbf{4 4}\end{array}$ & $\begin{array}{c}\text { Week } \\
\mathbf{4 8}\end{array}$ \\
\hline $\begin{array}{c}\text { Group I } \\
(\boldsymbol{\%})\end{array}$ & 0 & 0 & 0 & 0 & 0 & 3 & 2 & 9 & 4 & 3 & 4 & 7 & 9 & 8 \\
\hline $\begin{array}{c}\text { Group II } \\
(\boldsymbol{\%})\end{array}$ & 0 & 0 & 0 & 0 & 11 & 14 & 15 & 23 & 21 & 24 & 14 & 20 & 27 & 24 \\
\hline $\mathbf{X}^{\mathbf{2}}$ & 0.0 & 0.0 & 0.0 & 0.0 & 11.64 & 7.78 & 10.87 & 7.29 & 13.2 & 18.88 & 6.12 & 7.24 & 10.98 & 9.52 \\
\hline $\mathbf{P}$ & 1.0 & 1.0 & 1.0 & 1.0 & 0.001 & 0.005 & 0.001 & 0.007 & 0.001 & 0.001 & 0.013 & 0.007 & 0.001 & 0.002 \\
\hline
\end{tabular}

Group I (Study group), Group II (Control group) 
Table (6): The percentage of discontinuation of treatment in both groups.

\begin{tabular}{|l|c|c|c|c|c|c|}
\hline \multirow{2}{*}{} & \multicolumn{2}{|c|}{$\begin{array}{c}\text { Group I } \\
\text { (Study group) } \\
\text { (N=100) }\end{array}$} & \multicolumn{2}{c|}{$\begin{array}{c}\text { Group II } \\
\text { (Control group) } \\
\text { (N=100) }\end{array}$} & \multirow{2}{*}{$\mathbf{X}^{\mathbf{2}}$} & \multirow{2}{*}{$\mathbf{P}$} \\
\cline { 2 - 5 } & $\mathbf{N}$ & $\boldsymbol{\%}$ & $\mathbf{N}$ & $\mathbf{\%}$ & & \\
\hline Discontinuation: & & & & & & \\
Total & 5 & 8 & 6 & 6 & 0.31 & 0.58 \\
No EVR & 5 & 5 & 3 & 3 & 0.52 & 0.47 \\
Anemia & 1 & 1 & 2 & 2 & 0.34 & 0.56 \\
Neutropenia & 2 & 2 & 1 & 1 & 0.34 & 0.56 \\
\hline
\end{tabular}

\section{DISCUSSION}

Side effects of CHC treatment with Pegylated interferon and Ribavirin are believed to be, in part, due to oxidative stress induced by ribavirin.

In the present work we have studied the effect of antioxidants administered in conjunction with Pegylated interferon and Ribaverin in the amelioration of subjective and laboratory side effects of the combined therapy. We have used a mixture of four antioxidants with average therapeutic doses (slow release vitamin C $500 \mathrm{mg}$ daily, vitamin E $400 \mathrm{mg}$ daily, silymarin $420 \mathrm{mg}$ daily and $\mathrm{N}$-acetylcystein $600 \mathrm{mg}$ daily).

The results of our study revealed significant difference between both groups regarding changes in hemoglobin concentration along therapy from week one onwards as reduction in hemoglobin concentration along therapy was significantly lower in group 1 (study group); $\mathrm{p}=$ 0.001 . The frequency of significant anemia $(\mathrm{Hb}$ $<10 \mathrm{gm} / \mathrm{dl}$ ) in group 1 was significantly lower than Group 2 (control group) from week twelve onwards; $\mathrm{p}$ value ranged from 0.013 to 0.001 . This in turn resulted in much lower needs for dose modifications and hence more adherence to therapy in group 1 .

The etiology of anemia with antiviral therapy in CHC is multifactorial. It is caused mainly by ribavirin induced hemolysis. Interferon also may lead to suppression of the normal compensatory bone marrow response. The exact mechanism of ribavirin induced hemolytic anemia is unclear. Intracellular accumulation of phosphorylated metabolites of ribavirin leading to ATP depletion and oxidative damage of RBCs was suggested by De Franceschi et al. [7].

These results were consistent with Brass and Piken [11]; who have reported that administration of $1000 \mathrm{mg}$ of vitamin $\mathrm{C}$ and 800 $\mathrm{mg}$ of vitamin $\mathrm{E}$ daily together with antiviral therapy can reduce ribavirin induced hemolytic anemia. However, the number of patients included in their study was very low as it was just a pilot study that included twelve patients with CHC in the study group and fourteen patients in the control group whereas, the present study included 100 patients in each group. In the above mentioned study, the authors used standard INF alpha $2 \mathrm{~b}$ whereas, in the present study pegylated INF was used. Moreover, their patients were followed just for twelve weeks while in our study patients were followed for the whole 48 weeks.

These results were also consistent with Kawaguchi et al. [12]; who stated that administration of $2000 \mathrm{mg}$ of vitamin $\mathrm{C}$ and $2000 \mathrm{mg}$ of vitamin $\mathrm{E}$ daily together with antiviral therapy can reduce ribavirin induced hemolytic anemia. Doses of vitamins $\mathrm{E}$ and $\mathrm{C}$ used in the above study are much more than those used in our study. In the present work, two additional antioxidants namely silymarin and $\mathrm{N}$ acetylcystein (NAC) were given. Besides, the preparation of vitamin $\mathrm{C}$ used in the present work was a slow release form that allows prolonged effect of the vitamin. The number of patients included in the above study was also low, 21 patients in the study group and 21 patients in the control group, while our study included 100 patients in each group. Moreover, INF used was standard INF alpha $2 b$ while in our study we used pegylated INF.

Saeian et al. [13]; reported that the administration of 800 IU of vitamin E twice daily together with antiviral therapy did not reduce ribavirin-induced hemolytic anemia. This study included forty seven patients with CHC (27 vitamin $\mathrm{E} / 20$ controls). INF used was standard INF alpha 2b. By the end of this study, the 
authors recommended adding other antioxidants, like vitamin $\mathrm{C}$ or $\mathrm{NAC}$, to vitamin $\mathrm{E}$ to augment its antioxidant effect; which was done in our study. The results of the above study as well as the present work suggest that vitamin $\mathrm{E}$ alone is not effective in reducing ribavirin-induced hemolytic anemia and that the combination employed in the present work is more effective.

Neither of the previously mentioned studies has been conducted on patients with genotype four which is the predominant type in Egypt. Whether this observation has any relevance to the outcome of the studies remains to be elucidated.

Assem and Yousri [14]; stated that Pentoxifylline $800 \mathrm{mg}$ and vitamin E $1000 \mathrm{IU}$ daily can ameliorate RBV associated hemolytic anemia. These results are consistent with the results of our study. Pentoxifylline, TNF alpha antagonist, increase erythrocyte ATP and erythrocyte deformability resulting in reduction of RBCs hemolysis and augmenting vitamin $\mathrm{E}$ protective effect. This study was conducted in Egypt on genotype four using peginterferon $\alpha$ 2 b. This study was also conducted on 200 patients (100 in each group) which is comparable to the present study. However, their study has not focused on the other subjective side effects induced by antiviral therapy. To the date we have planned our study in 2009, these data were not yet published.

During antiviral therapy with Peginterferon and ribavirin, fatigue is a well documented side effect. The exact mechanism of fatigue is not clear; however, it is most likely multi-factorial, including the systemic effects of increased cytokines and treatment-related side effects such as anemia [15].

The results of the present study revealed significant difference between both groups regarding the frequency of fatigue from week two onwards till the end of therapy. The frequency was much lower in group I; $p$ value ranged from 0.027 to $<0.001$. This can be explained, in part, by the higher mean of hemoglobin concentration and the lower frequency of significant anemia in group I.

The results of our study revealed a nonsignificant statistical difference between both groups regarding neutrophilic count or the mean reduction in neutrophilic count along therapy. Regarding platelet count, there was also a nonsignificant statistical difference between both groups in all weeks of follow up during therapy apart from weeks sixteen and twenty eight where changes were significant. Moreover, there was a non-significant statistical difference between both groups regarding thyroid dysfunction (all cases reported were hypothyroidism).

Neutropenia and thrombocytopenia occurring with interferon therapy are mostly due to bone marrow suppression [16], although autoimmune related thrombocytopenia may also occur [17]. Thyroid dysfunction with INF therapy is mostly due to autoimmune mechanism. Oxidative stress seems to play no role with all these parameters and this may explain why they were not affected by antioxidants.

The results of our study revealed also a non significant difference between both groups in all other checked symptoms throughout the period of treatment including fever, headache, musculoskeletal symptoms (myalgia, arthralgia, bony pains), nausea, anorexia, weight loss, dry cough, insomnia, irritability, depression, alopecia (hair loss), injection site reactions and dermatological side effects (Itching, Rash, Dermatitis). The exact mechanisms of these side effects are not well understood. Oxidative stress has no clear role in these side effects and this may explain lack of benefit of antioxidants on these side effects.

Withdrawal from the study was comparable between the studied groups. Most of cases withdrawn due to lack of EVR, the rest due to hematological complications. Antioxidants had no effect on the frequency of treatment discontinuation.

Some previous studies have declared that erythropoietin can improve anemia caused by peginterferon and ribavirin therapy and is more effective than dose reduction at improving quality of life during treatment. However, erythropoietin has not yet been approved by FDA for the use in patients with HCV infection, in addition to its expensive costs [18].

In conclusion, it can be recommended to use the mixture of the four antioxidants used in the present study to ameliorate anemia and fatigue during treatment of $\mathrm{CHC}$ with pegylated interferon and ribavirin, as this can improve the quality of life and adherence to therapy.

Funding: None . 
Conflicts of interest: The authors declare that there is no conflict of interest.

Ethical approval: approved.

\section{REFERENCES}

1. Boya P, Pena A, Beloqui O, Larrea E, Conchillo M, Castelruiz Y, et al. Antioxidant status and glutathione metabolism in peripheral blood mononuclear cells from patients with chronic hepatitis C. $J$ Hepatol. 1999; 31: 808-814.

2. Lavanchy D, McMahon B. Worldwide prevalence and prevention of hepatitis C. In: Liang TJ, Hoofnagle JH, eds. Hepatitis C. San Diego, Academic Press 2000; 185-202.

3. Levent G, Ali A, Ahmet A, Polat EC, Aytaç C, Ayşe E, et al. Oxidative stress and antioxidant defense in patients with chronic hepatitis $\mathrm{C}$ patients before and after pegylated interferon alfa- $2 \mathrm{~b}$ plus ribavirin therapy. J Transl Med. 2006; 4: 25.

4. Fried MW, Shiffman ML, Reddy KR, Smith C, Marinos G, Gonçales FL, et al. Peginterferon alfa-2a plus ribavirin for chronic hepatitis $\mathrm{C}$ virus infection. $N$ Engl $J$ Med 2002; 347:975-82.

5. Keating GM, Curran MP. Peginterferonalpha-2a (40kD) plus ribavirin: a review of its use in the management of chronic hepatitis C. Drugs 2003; 63(7): 701-30.

6. Patterson JL, Fernandez-Larsson R. Molecular mechanisms of action of ribavirin. Rev Infect Dis 1990; 12: 1132-1146.

7. De Franceschi L, Fattovich G, Turrini F, Ayi K, Brugnara C, Manzato F, et al. Hemolytic anemia induced by ribavirin thera py in patients with chronic hepatitis $\mathrm{C}$ virus infection: role of membrane oxidative damage. Hepatology 2000; 31:997-1004.

8. Sies H. Oxidative stress: oxidants and antioxidants. Exp Physiol. 1997; 82 (2): 2915.

9. Choi J, Lee KJ, Zheng Y, Yamaga AK, Lai $\mathrm{MM}, \mathrm{Ou} \mathrm{JH}$. Reactive oxygen species suppress hepatitis C virus RNA replication in human hepatoma cells. Hepatology 2004; 39 (1): 81-89.
10. Singal AK, Jampana SC, Weinman SA. Antioxidants as therapeutic agents for liver disease. Liver Int. 2011 Nov; 31(10): 143248.

11. Brass CA, Piken E. Do antioxidants ameliorate ribavirin related anemia in $\mathrm{HCV}$ patients. Gastroenterol 1999; 116: L0056.

12. Kawaguchi Y, Mizuta T, Takahashi K, Iwane S, Ario K, Kawasoe H, et al. Highdose vitamins $\mathrm{E}$ and $\mathrm{C}$ supplementation prevents ribavirin-induced hemolytic anemia in patients with chronic hepatitis C. Hepatol Res. 2007 May; 37(5): 317-24.

13. Saeian K, Bajaj JS, Franco J, Knox JF, Daniel J, Peine C, et al. Highdose vitamin E supplementation does not diminish ribavirin-associated hemolysis in hepatitis $\mathrm{C}$ treatment with combination standard alpha-interferon and ribavirin. Aliment Pharmacol Ther. 2004 Nov 15; 20(10): 1189-93.

14. Assem M, Yousri M. Impact of Pentoxifylline and Vitamin E on RibavirinInduced Haemolytic Anaemia in Chronic Hepatitis C Patients: An Egyptian Survey. Int J Hepatol. 2011; 2011: 530949.

15. Sarkar S, Jiang Z, Evon DM Wahed AS, Hoofnagle JH. Fatigue before, during and after antiviral therapy of chronic hepatitis C: Results from theVirahepC study. J Hepatol. 2012 Nov;57(5):946-52.

16. Roomer R, Hansen BE, Janssen HL, De Knegt RJ. Risk factors for infection during treatment with peginterferon alfa and ribavirin for chronic hepatitis C. Hepatology 2010; 52(4): 1225-31.

17. Ong JP, Younossi ZM. Managing the hematologic side effects of antiviral therapy for chronic hepatitis $\mathrm{C}$ : Anemia, neutropenia, and thrombocytopenia. Cleveland Clinical Journal of Medicine 2004; 3: S17-21.

18. McHutchison JG, Manns MP, Brown RS, Reddy KR, Shiffman ML, Wong JB. Strategies for managing anemia in hepatitis $\mathrm{C}$ patients undergoing antiviral therapy. American Journal of Gastroenterology. 2007; 102(4): 880-889. 